\title{
A double-blind, placebo controlled trial of high-dose lecithin in Alzheimer's disease
}

\author{
ADRIENNE LITTLE,${ }^{*}$ RAYMOND LEVY, $\dagger$ PAZ CHUAQUI-KIDD,§ DAVID HAND \\ From the Departments of Psychology, ${ }^{*}$ the Section of Old Age Psychiatry $\dagger$ and the Biometrics Unit, $\ddagger$ Institute \\ of Psychiatry, and the Department of Psychological Medicine, Kings College Hospital, § London, UK
}

SUMMARY The first long-term double-blind placebo controlled trial of high dose lecithin in senile dementia of the Alzheimer type is reported. Fifty one subjects were given 20-25 g/day of purified soya lecithin (containing $90 \%$ phosphatidyl plus lysophosphatidyl choline) for six months and followed up for at least a further six months. Plasma choline levels were monitored throughout the treatment period. There were no differences between the placebo group and the lecithin group but there was an improvement in a subgroup of relatively poor compliers. These were older and had intermediate levels of plasma choline. It is suggested that the effects of lecithin are complex but that there may be a "therapeutic window" for the effects of lecithin in the condition and that this may be more evident in older patients.

Following the recognition of diminished levels of brain choline acetyltransferase in senile dementia of the Alzheimer type (SDAT) ${ }^{1-11}$ clinical approaches based on the "cholinergic hypothesis" 12 have been developed. One of these has been the use of choline or the choline precursor lecithin..$^{13-24}$ The matter has become more complicated as changes in other neurotransmitter systems have been reported ${ }^{25-37}$ and the general rationale of precursor loading has been questioned. ${ }^{38}$ In spite of these important theoretical issues, the therapeutic effectiveness of lecithin remains unknown. Clinical trials have reported disappointing results. ${ }^{34}$ However, these findings are difficult to interpret in view of the methodological shortcomings of most studies such as inadequate sample sizes, lack of controls, low doses of impure lecithin, often no placebo, no check on compliance and trials conducted over very brief periods with no follow-up.

The trial reported here has attempted to avoid these difficulties and was designed to test the hypothesis that high doses of lecithin might slow down the deterioration in relatively early cases of SDAT. To establish a differential rate of decline a double-blind placebo controlled design with rela-

Address for reprint requests: Prof R Levy, Institute of Psychiatry, De Crespigny Park, Denmark Hill, London SE5 8AF, UK.

Received 28 September 1984 and in revised form 6 December 1984. Accepted 10 December 1984 tively long treatment and follow-up periods was selected.

\section{Materials and methods}

\section{Subjects}

Potential subjects were obtained from various sources which included medical referrals to the hospital and other psychiatric services, direct referrals from the Alzheimer's Disease Society and a sample of elderly community residents (drawn from a large general practice or from residential homes) who were classified as possibly demented on the basis of their score on a brief screening questionnaire administered by a nurse. ${ }^{40}$ To be included, subjects had to fulfill several criteria.

(1) A clinical diagnosis of Alzheimer disease or SDAT established by a history of at least one year's progressive deterioration in intellectual function for which all other causes including diabetes, hypertension or head injury could be excluded.

(2) The absence of a history or physical signs of cerebro-vascular disease. This was established by a detailed history and examination of previous case notes. Any patient with an abrupt onset of dementia, a history suggestive of stroke or transient ischaemic attact, focal symptoms or focal signs was excluded, as were any patients with signs of hypertensive disease or with a diastolic blood pressure over $110 \mathrm{~mm}$ of $\mathrm{Hg}$.

(3) Performance was within a prescribed range on psychometric tests selected to monitor change. The difficulty level of these tests was set to be appropriate to the level of mild and moderate cases and the score such as to allow room either for improvement or for deterioration. 
Table 1 Psychometric tests and factor scores

\begin{tabular}{|c|c|}
\hline Factor scores & Tests \\
\hline $\begin{array}{l}\text { FAC } 1 \text { (verbal learning and } \\
\text { memory) }\end{array}$ & $\begin{array}{l}1 \text { Paired-Associate Learning Test } \\
\text { (immediate and delayed) } \\
2 \text { Verbal fluency } \\
3 \text { Orientation questionnaire } \\
\text { (All devised for the study) }\end{array}$ \\
\hline $\begin{array}{l}\text { FAC } 2 \text { (visuo-spatial and } \\
\text { constructional) }\end{array}$ & $\begin{array}{l}1 \text { Kew Tests } \\
2 \text { Incomplete Letters }{ }^{44} \\
3 \text { Cube Analysis } \\
4 \text { Digit Copy Test } \\
5 \text { Coloured Progressive Matrices }\end{array}$ \\
\hline FAC 3 (self care) & $\begin{array}{l}1 \\
2 \text { PADL scales } \\
2 \text { Physical Self Maintenance } \\
\text { Scale }^{54} \\
3 \text { Instrumental Activities of } \\
\text { Daily Living }\end{array}$ \\
\hline
\end{tabular}

(4) Subjects also had to be living with or near a reliable informant who could supervise their medication.

The initial assessment included a detailed medical and psychiatric history, and a neurological examination carried out by a psychiatrist with neurological experience, a standardised mental state examination for the elderly, ${ }^{41-43}$ and psychometric testing. Laboratory investigations included: blood urea and electrolytes, calcium, urate, cholestrol and random glucose level, liver function tests, serum B12 and folate, total and free $\mathrm{T} 4$, routine haematological and serological examination. CT scans and EEG were performed on all hospital cases (one half of the total) but not on subjects obtained from the lists of general practitioners as approval for these procedures was not given.

\section{Design}

Subjects were allocated randomly to the lecithin or placeo group and monitored blindly during a 6 month period and reassessed following a 6 month drug-free period. The two groups were studied in parallel with no cross-over.

\section{Preparations}

Soya bean lecithin containing a minimum of $90 \%$ phosphatidyl plus lysophosphatidyl choline was supplied by Unilever Research Laboratories. This was prepared as a sweetened and flavoured emulsion in water, resembling a thick milk shake. The placebo consisted of a similar looking and tasting emulsion of "Flora" margarine to which propylgallate and ascorbic acid were added as antioxidants. $100 \mathrm{ml}$ of suspension containing $25 \mathrm{~g}$ of lecithin was the dose selected and this was divided into two or three equal doses (depending on the subjects' choice) taken at mealtimes under the supervision of an informant.

Compliance was assessed throughout the study from informants' reports and by measuring the amount of preparation consumed. The overall measure of compliance was made at the end of the treatment period, subjects being classified as good compliers if they had taken consistently $\mathbf{7 5 \%}$ or more of the dose prescribed, and as poor compliers if they took less than this.

Free plasma choline levels were determined at baseline and after 1,2, 4 and 6 months of treatment. The estimation was carried out on a plasma ultrafiltrate using a radioenzymatic assay. 4445

Tests of orientation, learning and memory, perceptual and constructional skills and self care were administered. In view of the large number of tests used, it was determined that several hundred subjects would be required to analyse validly each test score as an individual dependent variable. Test scores were therefore reduced to three composite measures of different types of skill: orientation and verbal learning and memory (Factor 1) visuo-spatial and constructional skills (Factor 2) and self-care (Factor 3). These measures were derived by classifying tests according to content and extracting single measures of these by factor analysis (using IMAGE factoring). ${ }^{46}$ Factor 1 (FAC 1 ) was assessed at baseline and after 1,2, 4 and 6 months on treatment and after 6 months follow-up. Factors 2 (FAC 2) and 3 (FAC 3) were assessed at baseline, after 6 months treatment and after 6 months follow-up. It should be pointed out that on FAC 1 and 3 the higher the score the higher the ability whereas on FAC 2 high scores indicate impairment (table 1).

\section{Statistical treatment}

Simple camparisons between groups for individual variables were made using univariate analysis of variance. Multivariate techniques were used to compare groups overall on several variables at baseline and to examine differences in the pattern of changes shown during the treatment

Table 2 Baseline data for placebo and lecithin groups*

\begin{tabular}{|c|c|c|c|}
\hline Variable & $\begin{array}{l}\text { Placebo group } \\
N=17 \dagger\end{array}$ & $\begin{array}{l}\text { Lecithin group } \\
N=18+\end{array}$ & $\begin{array}{l}\text { Univariate } F \\
(d f 1,33)\end{array}$ \\
\hline $\begin{array}{l}1 \text { Age at start of trial } \\
2 \text { Duration of illness (years) } \\
3 \text { Neuro-psychiatric battery }\end{array}$ & $\begin{array}{r}74.82 \pm 12.52 \\
3.47 \pm 2.07\end{array}$ & $\begin{array}{r}76.83 \pm 9.27 \\
4.00 \pm 2.22\end{array}$ & $\begin{array}{l}1 \\
1\end{array}$ \\
\hline $\begin{array}{l}\text { - cortical dysfunction } \\
\text { - affective symptoms } \\
\text { - cognitive impairment } \\
4 \text { Plasma choline value (nmol/ml) } \\
\text { Psychometric test performance }\end{array}$ & $\begin{array}{l}14 \cdot 74 \pm 8 \cdot 45 \\
20 \cdot 35 \pm 14 \cdot 11 \\
14 \cdot 41 \pm 7 \cdot 40 \\
12 \cdot 71 \pm 5 \cdot 05\end{array}$ & $\begin{array}{l}10.97 \pm 8.04 \\
15.28 \pm 9.63 \\
11.33 \pm 5.37 \\
12.33 \pm 3.66\end{array}$ & $\begin{array}{l}1 \cdot 83 \\
1 \cdot 56 \\
2 \cdot 00 \\
1\end{array}$ \\
\hline $\begin{array}{l}\text {-FAC } 1 \text { (ability) } \\
\text {-FAC } 2 \text { (impairment) } \\
\text {-FAC } 3 \text { (ability) }\end{array}$ & $\begin{array}{r}50.43 \pm 24.05 \\
7.39 \pm 6.57 \\
25 \cdot 20 \pm 7.05\end{array}$ & $\begin{array}{r}47 \cdot 88 \pm 18.56 \\
1.99 \pm 7 \cdot 32 \\
29.41 \pm 6.04\end{array}$ & $\begin{array}{l}1 \\
5 \cdot 25 \ddagger \\
3 \cdot 60\end{array}$ \\
\hline
\end{tabular}

${ }^{*}$ Results given as mean \pm standard deviation

$\dagger N$ refers to subjects with complete data for all nine variables included in the multivariate analysis $\neq p<0.05$ 
Table 3 Baseline data: good and poor compliers on lecithin

\begin{tabular}{|c|c|c|c|}
\hline Variable & $\begin{array}{l}\text { Poor compliers* } \\
N=6 \dagger\end{array}$ & $\begin{array}{l}\text { Good Compliers* } \\
N=12 \dagger\end{array}$ & $\begin{array}{l}\text { Univariate } \\
F(d f 1,1 b)\end{array}$ \\
\hline $\begin{array}{l}1 \text { Age at start of trial } \\
2 \text { Duration of illness (years) } \\
3 \text { Neuro-psychiatric examination scores }\end{array}$ & $\begin{array}{r}83 \cdot 33 \pm 5 \cdot 96 \\
4 \cdot 50 \pm 1 \cdot 87\end{array}$ & $\begin{array}{r}73 \cdot 58 \pm 9.06 \\
3.75 \pm 2.42\end{array}$ & $\begin{array}{l}5 \cdot 63 \dagger \\
1\end{array}$ \\
\hline $\begin{array}{l}\text { - cortical dysfunction } \\
\text { - affective symptoms } \\
\text { - cognitive impairment } \\
4 \text { Plasma choline value }(\mathrm{nmol} / \mathrm{ml})\end{array}$ & $\begin{array}{r}13 \cdot 16 \pm 10 \cdot 73 \\
18 \cdot 00 \pm 10 \cdot 75 \\
9 \cdot 00 \pm 5 \cdot 14 \\
12 \cdot 83 \pm 3 \cdot 49\end{array}$ & $\begin{array}{r}9 \cdot 87 \pm 6 \cdot 61 \\
13 \cdot 92 \pm 9 \cdot 21 \\
12 \cdot 50 \pm 5 \cdot 30 \\
12 \cdot 08 \pm 3 \cdot 87\end{array}$ & $\begin{array}{l}1 \\
1 \\
1 \cdot 78 \\
1\end{array}$ \\
\hline $\begin{array}{l}\text {-FAC } 1 \text { (ability) } \\
\text {-FAC } 2 \text { (impairment) } \\
\text {-FAC } 3 \text { (ability) }\end{array}$ & $\begin{array}{r}48 \cdot 28 \pm 17 \cdot 65 \\
2 \cdot 63 \pm 5 \cdot 85 \\
26 \cdot 11 \pm 7 \cdot 06\end{array}$ & $\begin{array}{r}47 \cdot 68 \pm 20.20 \\
1.67 \pm 8.17 \\
31.05 \pm 4.99\end{array}$ & $\begin{array}{l}1 \\
1 \\
2 \cdot 99\end{array}$ \\
\hline
\end{tabular}

${ }^{*}$ Results given as mean \pm standard deviation

$\dagger \mathrm{N}$ refers to subjects with complete data for all nine variables included in the multivariate analysis $\ddagger \mathrm{p}<0.05$

period on plasma choline levels and FAC 1 . These changes were described by polynomial analyses of trend which examine and compare the shapes of curves. Five data points were considered (baseline and after 1,2, 4 and 6 months on treatment) and the linear (straight line), quadratic (one reversal of trend, or "bend"), cubic (two reversals of trend or "bends") and quartic (three reversals of trend or "bends") components of the changes shown during this period calculated and compared for the groups.

\section{Results}

\section{Sample}

Potential subjects numbering 296 were considered of whom 82 fulfilled the inclusion criteria. Nineteen refused to participate, 12 withdrew during treatment and three died during follow-up, leaving 51 subjects who completed treatment ( 26 on placebo, 25 on lecithin) and 48 who completed the full year (24 in each group). Overall the two groups were comparable at baseline (table 2) and there were no differences in sex or source of referral. However the placebo group was significantly more impaired on FAC 2 (Univariate $F=5.25 ;$ df 1,$33 ; p<0.05$ ) and there was considerable heterogeneity within both

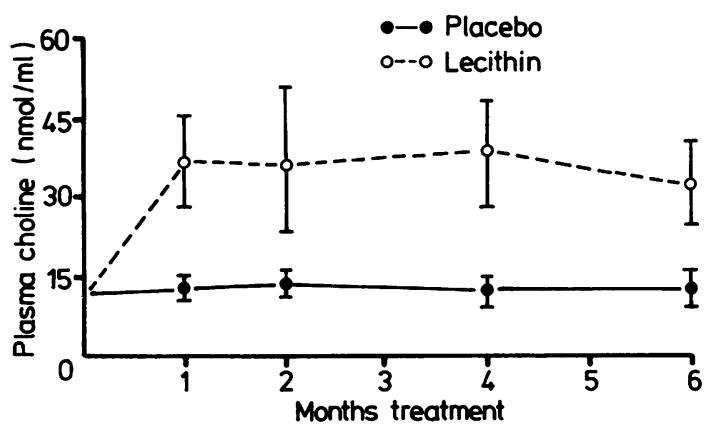

Fig 1 Mean plasma choline levels in lecithin and placebo group groups for most measures.

\section{Compliance and tolerance}

Many subjects found the six months treatment period long and the preparations unpalatable. Only a few reported side-effects ( 17 of the 63 who started on the trial) complaining of gastrointestinal discomfort (either diarrhoea or a feeling of excessive fullness in the abdomen) or nausea which disappeared in all cases when the dose was reduced to $20 \mathrm{~g}$. The weight gain reported in previous studies using impure lecithin was not a problem. There were more drop-outs from the lecithin group than from the placebo group (nine compared with three), more complaints of side-effects (14 compared with three) and more poor compliers (eight compared with four). Good and poor lecithin compliers were compared at baseline (table 3). Overall there were no significant differences (Multivariate $F=1.46$; df 9,$8 ;$ N.S.) but the poor compliers were significantly older (Univariate $F=5.63$; df 1,$16 ; p<0.05$ ).

\section{Plasma choline values}

As predicted, lecithin significantly raised plasma choline values throughout the six months of treatment $($ Drug $\times$ Time interaction; Multivariate $F=$

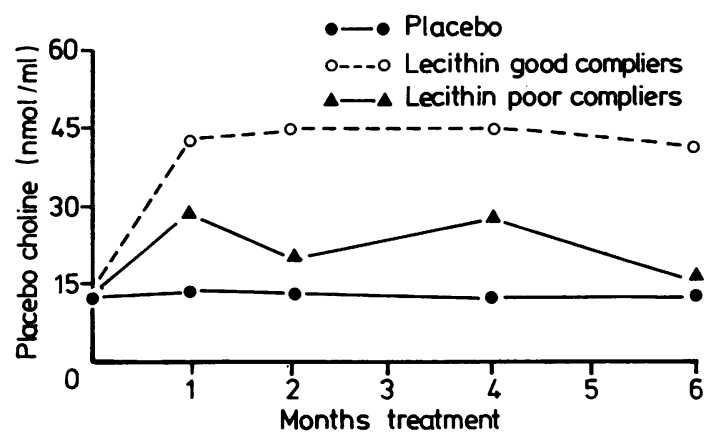

Fig 2 Plasma choline levels in three separate groups 


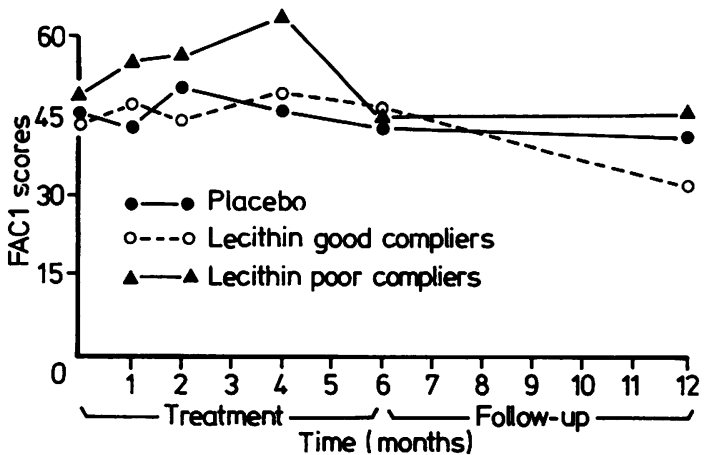

Fig 3 Factor 1 scores (learning \& memory) in three groups of patients

$12 \cdot 11 ;$ df 4,$32 ; p<0.001$ ) (fig 1 ). This elevation of choline value was a function of compliance to lecithin (Drug $\times$ Time $\times$ Compliance interaction; Multivariate $F=2.74$; df 4,$30 ; p<0.05$ ). Poor compliers showed elevated levels of choline values relative to the placebo group but this increase was almost half that shown by the good compliers and was maintained for the first four months of treatment only (fig 2).

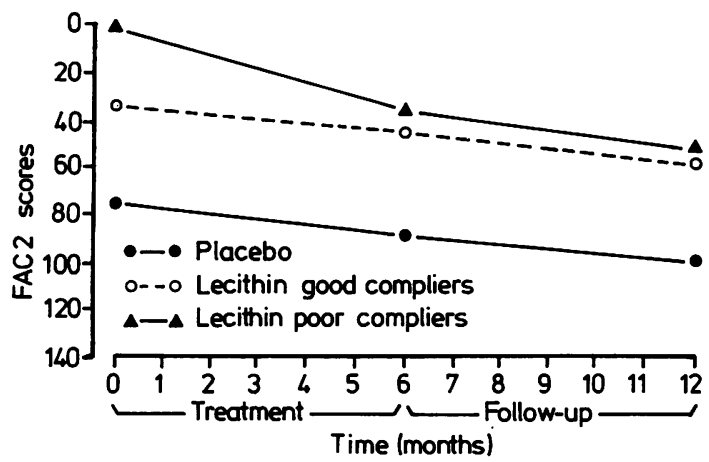

Fig 4 Factor 2 scores (visuo-spatial \& constructional) in three groups of patients

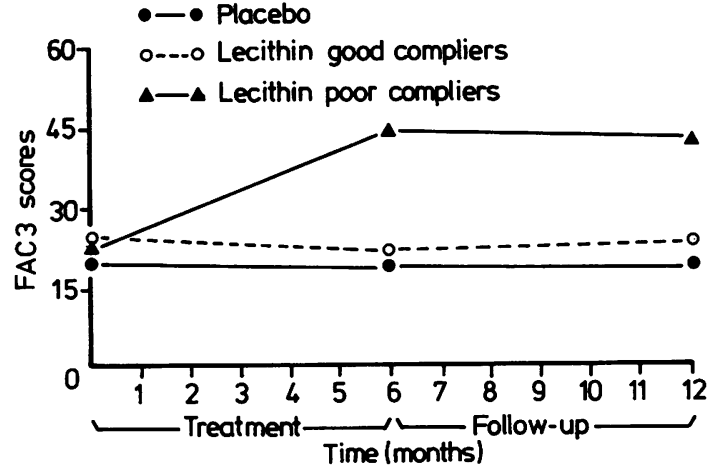

Fig 5 Factor 3 scores (Self-care) in three groups of patients

\section{Changes in test performance}

When the two main groups (placebo and lecithin) were compared there were no significant differences on any of the three measures of change during treatment or follow-up. However in view of the relatively large number of poor compliers and the general impression that some subjects had responded better than others, a separate comparison of the good compliers, the poor compliers and the placebo group was carried out. Mean scores for these three groups on the three psychometric measures are shown in figs 3,4 and 5 .

Against expectations poor compliers appear to do best and improved during the treatment period on FAC 1 and FAC 3. Good compliers and placebo subjects show similar, slight changes during this period. The changes shown by poor compliers were compared with those shown by good compliers and by the placebo group.

For FAC 1 the overall mutlivariate comparisons of these changes did not quite reach acceptable levels of significance. However, for both comparisons the quadratic component of these changes was significant suggesting differences in the pattern of changes shown during treatment (table 4).

From fig 3 it seems that whereas good compliers

Table 4 Statistical analysis of comparision between placebo group, poor compliers and good compliers

\begin{tabular}{|c|c|c|}
\hline & $\begin{array}{l}\text { Poor compliers }(N=6) \text { vs } \\
\text { Placebo subjects }(N=24)^{*}\end{array}$ & $\begin{array}{l}\text { Good compliers }(N=12) \text { vs } \\
\text { Poor compliers }(N=6)^{*}\end{array}$ \\
\hline $\begin{array}{l}\text { Multivariate Comparisons of Changes (Group } \times \text { Time } \\
\text { Interaction) } \\
\text { Univariate Comparisons of Polynomial Components of } \\
\text { Changes: } \\
\text { (a) linear } \\
\text { (b) quadratic } \\
\text { (c) cubic } \\
\text { (d) quartic }\end{array}$ & $\begin{array}{l}F=2.4 ; \text { df } 4,26 \\
p<0.08 \\
\text { Step-down Test: } \\
\text { df } 1,29 \\
F=0.01 \\
F=4.93 ; p<0.03 \\
F=3.39 \\
F=0.75\end{array}$ & $\begin{array}{l}F=1 \cdot 8 ; \text { df } 4,14 \\
p<0 \cdot 16 \\
\text { Step-down Test: } \\
\text { df } 1,17 \\
F=0.32 \\
F=6.25 ; p<0.02 \\
F=0.84 \\
F=0.43\end{array}$ \\
\hline
\end{tabular}

${ }^{*} \mathrm{~N}$ refers to subjects with complete data for FAC 1 
and placebo subjects showed slight fluctuations in performance during the 6 month treatment period the scores of poor compliers improved consistently during the first four months on lecithin but then fell to baseline levels at 6 months. For FAC 2 no group differences were significant. For FAC 3 , the changes shown by good and poor compliers during treatment were significantly different (univariate $F=6.64$; df. $1,20 ; \mathrm{p}<0.01)$ but the differences between poor compliers and palcebo subjects just failed to reach significance (univariate $F=3.80 ;$ df. 1,$26 ; p<$ $0 \cdot 06$ ). Whereas good compliers and placebo subjects showed slight changes during the treatment period there was a marked improvement in the performance of poor compliers (fig 5).

Since there was a significant difference in age between good and poor compliers and between poor compliers and placebo, differences between the groups were re-examined using analysis of covariance to control for age. Similar results were found. However the analysis of trend for FAC 1 now failed to reach significance but significant group differences were found consistently for FAC 3 when comparing good with poor compliers (Univariate $\mathrm{F}$ $=7 \cdot 70 ; \mathrm{df} 1,18 ; \mathrm{p}<0.01)$ and poor compliers with placebo subjects (Univariate $F=4 \cdot 64$; df 1,24; $p<$ $0 \cdot 05)$.

\section{Discussion}

The effects of lecithin on psychometric test performance were complex and unpredicted. Thus, although as a whole there were no significant differences between the lecithin and placebo groups, when other factors such as compliance, plasma choline levels and age were taken into account interesting trends emerged. We had expected that good compliers would fare better. In fact the reverse was the case. In so far as a "responder" subgroup might be identified it was the relatively poor compliers who did best. They showed moderate improvement in FAC 1 (orientation, learning and memory) at four months, a time when their plasma choline level was just below twice the baseline value. This improvement was not maintained at six months by which time plasma choline had returned to baseline level. We suspect that this is because the patients had by then stopped taking any lecithin at all. The possibility that the drop in plasma choline in the poor-complier group might be due to enzyme induction cannot be excluded. A decline in plasma choline on an apparently fixed dose of lecithin has previously been reported ${ }^{47}$ but it should be noted that no such decline was found in the good complier group and the time course is probably inconsistent with the possibility of enzyme induction.
On FAC 3 (activities of daily living) there was a substantial improvement at six months and this was maintained after six months follow-up. Unfortunately since the assessments concerned were not carried out at four months no direct comparison with the transient improvements in memory and orientation can be carried out.

FAC 2 (visuo-spatial and constructional skills) showed a very slight decline in all three groups throughout the period of treatment and follow-up period.

A question then arises as to the comparability between the poor-compliers and the rest. It will be noted that they were older and that when the effects of age were controlled for the differences in FAC scores were no longer significant but those for FAC 3 became greater.

Rossor et $\mathbf{l}^{37}$ have shown that older patients with Alzheimer's disease are more likely to have a pure cholinergic deficit and it is conceivable that at least part of the difference between poor compliers and good-compliers might be related to age. However this would only account for the effects in orientation, learning and memory but not for those on self-care which remained significant when age was controlled for. There remains the possibility that the groups might have differed in some other as yet unidentified feature which might have differentially affected the course of the disease in the poorcomplier group.

The final explanation is that there might be a therapeutically optimal dose of lecithin which poor compliers may have received by chance. A similar "therapeutic window" has been described for other cholinergic agonists such as physostigmine ${ }^{55-57}$ and it is conceivable that a plasma-choline level around twice the baseline value should be aimed at.

The effects of lecithin on the course of SDAT are therefore complex and it is certainly premature to abandon attempts to establish when and how it should be used. Although caution is required in the interpretation of the results the present study suggests that some subjects may respond to moderate doses. The present data do not allow us to conclude whether this applies to all patients with the condition. The effects seem to take several months to develop and they may be restricted to changes in certain important skills. The results clearly require replication and future studies should be directed at trying to disentangle the effects of age, plasma choline levels and other factors.

We thank the numerous colleagues who referred cases for the trial; Mrs Margaret Reith and Mrs Lynne Johnston for their invaluable help in screening subjects and carrying out numerous assessments; 
Mr Basil Ashkenasy and the staff of the pharmacy at the Maudsley Hospital for mixing and storing the preparations; Dr Roger Marchbanks for advice about the choline assays; Mrs Jean Perkins and Mrs Nadine Morgan for secretarial assistance and the staff and residents of numerous old people's homes for their forbearance. The lecithin was supplied by Unilever Research Laboratories and the work was supported by the Medical Research Council.

\section{References}

' Bowen DM, Smith CB, White P, Dawson N. Neurotransmitter-related enzymes and indices of hypoxia in senile dementia and other abiotrophies. Brain 1976;99:459-96.

${ }^{2}$ Bowen DM, Spillane JA, Curzon G, et al. Accelerated aging or selective neuronal loss as an important cause of dementia. Lancet 1979;1:11-14.

${ }^{3}$ Davies P, Maloney AJ. Selective loss of central cholinergic neurons in Alzheimer's disease. Lancet 1976;ii: 1403.

${ }^{4}$ Perry EK, Perry RH, Blessed G, Tomlinson BE. Necropsy evidence of central cholinergic deficits in senile dementia. Lancet 1977; i: 189.

s Perry EK, Gibson PH, Blessed G, Perry RH, Tomlinson BE. Neurotransmitter enzyme abnormalities in senile dementia. J Neurol Sci 1977;34:247-65.

- Perry EK, Perry RH, Gibson PH, Blessed G, Tomlinson BE. A cholinergic connection between normal aging and senile dementia in the human hippocampus. Neurosci Let 1977;6:85-9.

${ }^{7}$ Perry EK, Tomlinson BE, Blessed G, Bergmann K, Gibson PH, Perry RH. Correlation of cholinergic abnormalities with senile plaques and mental test scores in senile dementia. Br Med J 1978;ii:1457-9.

${ }^{8}$ White P, Goodhart MJ, Keet JP, Hiley CR, Carrasco LH, Williams IEI. Neocortical cholinergic neurons in elderly people. Lancet $1977 ; \mathbf{i}: 668-71$.

${ }^{4}$ Wilcock GK, Esiri MM, Bowen DM, Smith CCT. Alzheimer's disease. Correlation of cortical choline acetyltransferase activity with the severity of dementia and histological abnormalities J Neurol Sci 1982; 57:407-17.

${ }^{10}$ Bowen DM, Benton JS, Spillane JA, Smith CCT, Allen SJ. Cholineacetyltransferase activity and histopathology of frontal neocortex from biopsies of demented patients. J Neurol Sci 1982;57:191-202.

" Simms NR, Bowen DM, Allen SJ, et al. Presynapatic cholinergic dysfunction in patients with dementia. $J$ Neurochem 1983;40:503-9.

12 Bartus RT, Dean RL III, Beer B, Lippa AS. The cholinergic hypothesis of geriatric memory dysfunction. Science 1982;217:408-17.

${ }^{13}$ Boyd WD, Graham-White J, Blackwood G, Glen I, McQueen J. Clinical effects of choline in Alzheimer senile dementia. Lancet 1977;ii:711.

${ }^{14}$ Etienne P, Gauthier S, Johnson G, et al. Clinical effects of choline in Alzheimer's disease. Lancet 1978;i:508-9.
15 Signoret JL, Whiteley A, L'Hermitte F. Influence of choline on amnesia in early Alzheimer's disease. Lancet 1978;ii: 837.

${ }^{16}$ Smith CM, Swash M, Exton-Smith AN, et al. Choline therapy in Alzheimer's disease. Lancet 1978;ii: 318.

${ }^{17}$ Smith CM, Swash M, Exton-Smith AN. Effects of cholinergic drugs on memory in Alzheimer's disease. In: Glen AIM, Whalley LJ, eds. Alzheimer's Disease: Early Recognition of Potentially Reversible Deficits. Edinburgh: Churchill Livingstone, 1979;148-53.

${ }^{18}$ Whiteley A, Signoret JL, Agid Y, L'Hermitte F. Action de la choline sur les troubles mnesiques de la maladie d'Alzheimer. Rev Neurol (Paris) 1979;135:565-72.

${ }^{14}$ Renvoize EB, Jerram T. Choline in Alzheimer's Disease. New Engl J Med 1979;301:330.

${ }^{20}$ Vroulis GA, Smith RC, Brinkman S, Schoolar J, Gordon J. The effects of lecithin on memory in patients with senile dementia of the Alzheimer's type. Psychopharm Bull 1981;17:127-8.

${ }^{21}$ Gauthier S, Etienne P, Dastoor D, Collier B, Ludwick R. Lack of an effect of a 3 month treatment with lecithin in Alzheimer's disease. Neurology (NY) 1981;31:1552-4.

${ }^{22}$ Drachman DA, Glosser G, Flemming P, Longenecker G. Memory decline in the aged; treatment with high dose lecithin. Neurology (NY) 1981;31:101.

${ }^{23}$ Fisman M, Merskey H, Helmes E, McCready J, Coulhon EH, Rylett BJ. Double blind study of lecithin in patients with Alzheimer's disease. Can J Psychiatry 1981;26:426-8.

${ }^{24}$ Brinkman SD, Smith RC, Meyer JS, et al. Lecithin and memory training in suspected Alzheimer's disease. $J$ Gerontol 1982;37:4-9.

2s Adolfsson R, Gottfries CG, Oreland L, Roos BE, Winblad $\mathrm{B}$. Reduced levels of catecholamines in brain and increased activity of MAO in platelets. In: Katzman R, Terry RD, eds. Alzheimer's Disease-Therapeutic Implications in Alzheimer's Disease, Senile Dementia and Related Disorders. New York: Raven Press, 1978:441-51.

${ }^{26}$ Adolfsson R, Gottfries CG, Roos BE, Winblad B. Changes in the brain catecholamines of patients with dementia of the Alzheimer type. Br J Psychiatry 1979; 135:216-23.

${ }^{27}$ Yates C, Allison Y, Simpson J, Maloney AFJ, Gordon A. Dopamine in Alzheimer's disease and senile dementia. Lancet 1979;ii: 851-2.

${ }^{28}$ Cross AJ, Crow TJ, Perry EK, Perry RH, Blessed G, Tomlinson BE. Reduced dopamine-beta-dydroxylase activity in Alzheimer's disease. $\mathrm{Br}$ Med J 1981; 282: 93-4.

${ }^{24}$ Tomlinson BE, Irving D, Blessed G. Cell loss in the locus coeruleus in senile Dementia of Alzheimer type. J Neurol Sci 1981;49:419-28.

${ }^{30}$ Bondareff W, Mountjoy CQ, Roth M. Selective loss of neurones of origin of adrenergic projection to cerebral cortex (nucleus locus coeruleus) in senile dementia. Lancet 1981;i: 783-4.

${ }^{31}$ Perry EK, Tomlinson BE, Blessed G, Perry RH, Cross AJ, Crow TJ. Neuropathology and biochemistry observations on the nonadrenergic system in Alzheimer's disease. J Neurol Sci 1981;51:279-87. 
${ }^{32}$ Mann JJ, Stanley M, Neuphytides A, De Leon MJ, Ferris SH, Gershon S. Central amine metabolism in Alzheimer's disease: in vivo relationship to cognitive deficit. Neurobiol Aging 1981;2:57-60.

${ }^{33}$ Smith RC, Ho BT, Kralik P, et al. Platelet MAO in Alzheimer's disease. J Gerontol 1982;37:572-4.

${ }^{34}$ Yates CM, Ritchie IM, Simpson J, Maloney AFJ, Gordon A. Noradrenaline in Alzheimer type dementia and Down syndrome. Lancet 1981;ii:39-40.

${ }^{35}$ Mann DM, Yates PO. Serotonin nerve cells in Alzheimer's disease. J Neurol Neurosurg Psychiatry 1983;46:96.

${ }^{36}$ Aziz AA, Leeming RJ, Blair JA. Tetrahydrobiopterin metabolism in senile dementia of Alzheimer type. $J$ Neurol Neurosurg Psychiatry 1983;46:410-13.

${ }^{37}$ Rossor MN, Garrett NJ, Johnson AL, Mountjoy CQ, Roth M, Iversen LL. A post-mortem study of the cholinergic and GABA systems in senile dementia. Brain 1982; 105:313-30.

${ }^{38}$ Marchbanks RM. Choline, acetylcholine and dementia. Editorial. Psychol Med 1980;10:1-3.

${ }^{34}$ Editorial. Drugs and memory. Lancet 1982;ii:474-6.

${ }^{40}$ Bergmann K, Gaber LB, Foster EM. The development of an instrument for early ascertainment of psychiatric disorder in elderly community residents: a pilot study. In: Degkwitz R, Rodebold H, Schulz PW, eds. Janssen Symposium: Gerontopsychiatry. Dusseldorf: 1975; 4:84-119.

${ }^{41}$ Copeland JRM, Kelleher MJ, Kellett JM, et al. A semistructured clinical interview for the assessment of diagnosis and mental state in the elderly: the Geriatric Mental State Schedule: I. Development and reliability. Psychol Med 1976;6:439-49.

${ }^{42}$ Gurland BJ, Fleiss JL, Goldberg K, et al. A semistructured clinical interview for the assessment of diagnosis and mental state in the elderly: the Geriatric Mental State Schedule. II. A factor analysis. Psychol Med 1976;6:451-9.

${ }^{43}$ Henderson AS, Duncan-Jones P, Finlay-Jones RA. The reliability of the Geriatric Mental State Examination. Community survey version. Acta Psychiatr Scand 1983;67:281-9.
${ }^{44}$ Goldberg AM, McCaman RE. The determination of picomole amounts of acetylchone in mammalian brain. J Neurochem 1973;20:1-8.

45 Wang FL, Haubrich DR. A simple, sensitive and specific assay for free choline in plasma. Anal Biochem 1975; 63: 195-201.

${ }^{46}$ Nie NH, Hull CH, Jenkins JG, Steinbrenner K, Bent DH. Stakshcat Package for the Social Sciences. New York, McGraw-Hill. 1975.

${ }^{47}$ Chamberlain S, Robinson N, Walker JS, et al. Effect of lecithin on disability and plasma free-choline levels in Friedreich's ataxia. J Neurol Neurosurg Psychiatry 1980;43:843-5.

${ }^{48}$ McDonald C. Clinical heterogeneity in senile dementia. Br J Psychiatry 1969;115:267-71.

${ }^{44}$ Warrington EK, James M. Disorders of visual perception in patients with localised cerebral lesions. Neuropsychologia 1967;5:253-66.

so Warrington EK, Robin P. Perceptual matching in patients with cerebral lesions. Neuropsychologia 1970;8:475-87.

st Kendrick DC. The Kendrick battery of tests: Theoretical assumptions and clinical uses. Br J Soc Clin Psychol 1972; 11:373-86.

52 Raven JC. The Coloured Progressive Matrices. London: HK Lewis \& Co. 1977.

${ }^{53}$ Kuriansky JB, Gurland BJ, Fleiss JL, Cowan D. The assessment of self-care capacity in geriatric psychiatric patients by objective and subjective methods. J Clin Psychol 1974;32:95-102.

${ }^{54}$ Lawton MP, Brody EC. Assessment of old people: self maintaining anci instrumental activities of daily living. Gerontologist 1969;9:179-86.

ss Deutsch JA. The cholinergic synapse and the site of memory. Science 1971;174:788-94.

${ }^{56}$ Christie JE, Shering A, Ferguson J, Glen AIM. Physostigmine and arecoline: effects of intravenous infusions in Alzheimer's Presenile Dementia. $\mathrm{Br} J$ Psychiatry 1981;138:46-50.

${ }^{57}$ Thal LJ, Fuld PA, Masur DM, Sharpless NS. Oral Physostigmine and lecithin improve memory in Alzheimer Disease. Ann Neurol 1983;13:491-6. 